\title{
A SURVEY OF THE EUTROPHICATION STATE OF AN URBANIZED TROPICAL ESTUARY, THE CASE OF THE GREAT VITÓRIA ESTUARINE SYSTEM, BRAZIL.
}

\author{
GRILO, C.F. ${ }^{1 *}$; BOINA, C.D. ${ }^{2} ;$ PINTO, T.K.O. ${ }^{2,3}$; VICENTE, M.A. ${ }^{4,6}$; CASTRO, E.V.R ${ }^{4}$; BARROSO, G.F.; \\ NETO, R.R. ${ }^{1}$ \& SANTOS, C. C. ${ }^{1}$
1. Laboratório de Geoquímica Ambiental (LabGAm), Departamento de Oceanografia e Ecologia, Universidade Federal do Espírito Santo, Vitória, ES, Brazil.
2. Laboratório de Bentos, Departamento de Oceanografia e Ecologia, Universidade Federal do Espírito Santo, Vitória, ES, Brazil. \\ 3. Present Address: Laboratório de Ecologia Bentônica, Unidade de Ensino Penedo, Campus \\ Arapiraca, Universidade Federal de Alagoas, Penedo, AL, Brazil. \\ 4. Laboratório de Petróleo (LabPetro), Departamento de Química, Universidade Federal do Espírito \\ Santo, Vitória, ES, Brazil. \\ 5. Laboratório de Limnologia e Planejamento Ambiental, Departamento de Oceanografia e Ecologia, \\ Universidade Federal do Espírito Santo, Vitória, ES, Brazil. \\ *Corresponding author: carolinegrilo@gmail.com
}

\begin{abstract}
Grilo, C.F.; Boina, C.D.; Pinto, T.K.O.; Vicente, M.A.; Castro, E.V.R; Barroso, G.F.; Neto, R.R. \& Santos, C.C., (2016). A survey of the eutrophication state of an urbanized tropical estuary, the case of the Great Vitória Estuarine System, Brazil.. Braz. J. Aquat. Sci. Technol. 20(1). eISSN 1983-9057. DOI: 10.14210/bjast.v20n1. Although, estuarine ecosystems have an ecological and economical importance as they have a high biological productivity and occur within a unique and dynamic environment, they have been subjected to anthropogenic alterations. The Great Vitória Estuarine System (GVES), Espírito Santo State, Brazil, is not an exception, as urbanization is growing around it with a high quantity of sewage been added to the system. In order to evaluate the eutrophication state as well as the meiofauna response to it, several parameters in both sediments and in the water column were assessed. Orthophosphate, nitrite, nitrate, ammonia, chl a and Fecal Coliform counts $(\mathrm{FC})$ ranged from 0.2 to $3.2 \mu \mathrm{M}, 0.25$ to $1.14 \mu \mathrm{M}, 1.83$ to $20.19 \mu \mathrm{M}, 4.19$ to $49.23 \mu \mathrm{M}$, 0.61 to $6.72 \mu \mathrm{g} / \mathrm{L}$ and 14 to $5.0 \times 10^{4} \mathrm{MPN} / 100 \mathrm{~mL}$ of water, respectively. These results showed that the GVES is under an eutrophication process and that the Passagem Channel experienced the largest impacts. Sewage plays an important role in this eutrophication process as indicated by PCA and correlations tests. The density of meiofauna showed similar values to those found in environments with similar levels of anthropogenic stress. This multi-approach evaluation revealed several aspects of the impacted estuary and could be used as an important tool to manage better the estuary.
\end{abstract}

Key words: Estuary, Meiofauna, Nutrients, Organic matter, Sediments, Sewage.

\section{INTRODUCTION}

Estuarine ecosystems have an ecological and economical importance as they have a high biological productivity and occur within a unique and dynamic environment. Mangroves in tropical and subtropical estuaries act as nurseries for many species and also provide physical protection to coastal erosion. However, a lack of adequate planning of human activities has lead to several environmental problems, including eutrophication, chemical and microbial contamination, leading to changes in biological communities and the loss of ecosystem goods and services. The Great Vitória Estuarine System (GVES) is no exception to these problems. The GVES consists of several tributaries (Santa Maria da Vitoria, Bubu, Itanguá, Marinho and Aribiri), a mangrove area, the Passagem Channel and Vitoria Bay. Over the years, the GVES has received different inputs of domestic, industrial, port and agri- cultural effluents, including treated and raw sewage from the Vitoria, Vila Velha and Cariacica urban areas.

Although Vitoria Bay and Passagem Channel have been impacted negatively, the exact state of eutrophication has not yet been characterized. To better manage the GVES and to improve the quality of life of the population (>1,500,000 inhabitants) in the area, it is necessary to evaluate the environmental quality of this estuarine system. To provide an effective management system to the GVES that aims to restore environmental quality, pollution and contamination indicators must be assessed.

Sterza et al. (2008) studied the effects of physico-chemical variables and nutrients on zooplankton distribution and abundance at the GVES and suggested that the estuary may be in the process of eutrophication. When a system is eutrophic, it is important to identify the process drivers, which can be induced by natural or anthropogenic factors. Several 
factors can be examined to determine the eutrophic state of a system and generally involve the assessment of fecal coliforms (FC) and nutrient or organic matter (OM) inputs into the system. The FC bacterial count is often used to indicate pollution, particularly domestic sewage. High concentrations of dissolved nutrients, namely nitrogen and phosphorus, both in the water column and sediments, are other good indicators of eutrophication. The addition of sewage increases the levels of nutrients directly or indirectly (via OM remineralization), supporting algal blooms (Braga et al., 2000; Paerl, 2009). OM added or senescent algae remineralization will decrease dissolved oxygen (DO) levels, which can also be used as an indicator of water quality. Anoxic coastal waters have been associated with the decay of micro- and macro-algae that show an intense growth due to eutrophication (Johannessen \& Dahl, 1996; Simpson, 2001).

In this context, sediments from the GVES were analyzed for total sediment organic matter (SOM) and meiofauna community structure descriptors such as: density and group's diversity. Water samples were analyzed for FC, dissolved nutrients (nitrate, nitrite, ammonia, orthophosphate), chlorophyll a (chl a), salinity, DO, total particulate matter (TPM) and total organic particulate matter (TOPM) to elucidate the eutrophication level as well as the meiofauna response to these factors in the GVES as a case study of a complex polluted tropical estuary.

\section{MATERIALS AND METHODS}

\section{Sampling}

Sampling was carried out at 18 stations around Vitória Island in the GVES on April 2005 during the ebb tide (Fig. 1). Surface water was collected with a Niskin bottle and was stored in polyethylene flasks (sterilized for FC analysis). Aliquots of the top two centimeters of the sediments were taken from samples collected with an Ekman and a Van Veen grab and were then stored in glass bottles. All samples were cooled during transport to the lab, where they were stored at $-20^{\circ} \mathrm{C}$. Dissolved oxygen and salinity were analyzed in situ using a calibrated YSI multi-parameter.

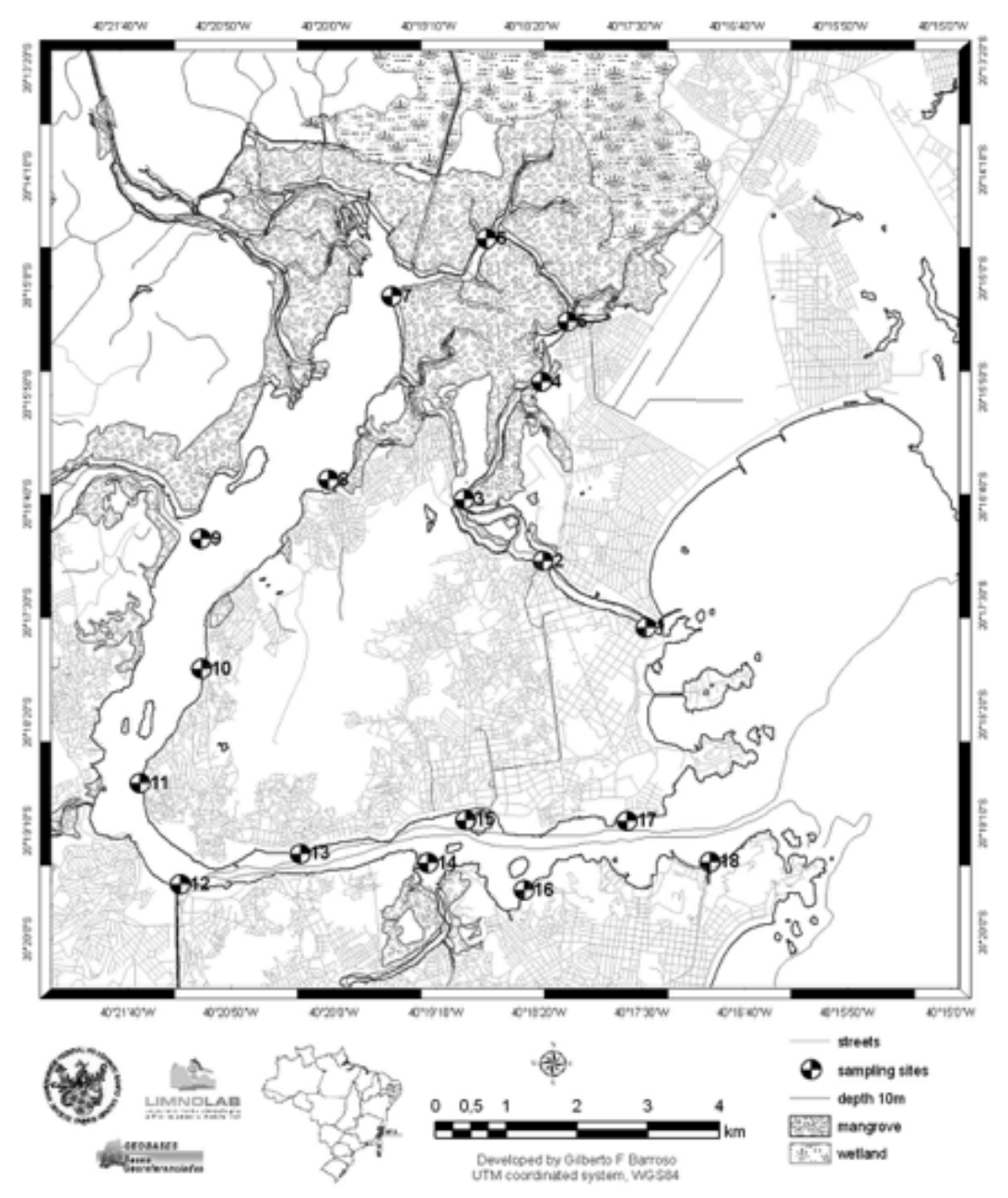

Figure 1 - Sampling stations around Vitória Island within the Great Vitoria Estuarine System (GVES). 


\section{Nutrients}

Orthophosphate, nitrite, nitrate, and ammonia were analyzed as in Murphy \& Riley (1962), Bendschneider \& Robinson (1952), Wood et al. (1967; using $\mathrm{NH}_{4} \mathrm{Cl}$ instead of EDTA), and Strickland \& Parsons (1972), respectively, after water samples were filtered with a Whatman $934 \mathrm{AH}$ 24-mm glass fiber filter.

\section{Chlorophyll a}

Water samples were filtered immediately after sampling with Whatman $934 \mathrm{AH}$ 24-mm glass fiber filters that were kept in glass jars stored in the dark on ice. Chl a was extracted with $10 \mathrm{ml}$ of a $90 \%$ acetone solution within $24 \mathrm{~h}$. The concentration was determined by a fluorimetric method with pheopigment acidification according to Strickland \& Parsons (1972).

\section{Fecal coliforms}

The multiple tubes method was used with four dilutions and a five-tube series. Sample inoculums were made up to eight hours after sampling utilizing the reagent Merck A1 as a culture media (APHA, 1999).

\section{Total sediment organic matter}

Sediment was lyophilized, and the organic content was estimated by combusting two grams of the sediment samples at $550^{\circ} \mathrm{C}$ for five hours and reweighing the samples.

\section{Total particulate matter and total organic particulate matter}

A $200 \mathrm{ml}$ water sample from each sampling station was filtered in a Whatman $934 \mathrm{AH} 24 \mathrm{~mm}$ preweighed glass filter. Filters were then dried at $60^{\circ} \mathrm{C}$ in a stove for two hours and were reweighed for TPM determination. Filters were then combusted (at $550^{\circ} \mathrm{C}$ for $5 \mathrm{~h}$ ) and reweighed for TOPM analyses.

\section{Meiofauna}

Sediments collected with a Van Veen grab were sub-sampled in triplicate with a PVC core (threecentimeter inner diameter) for meiofauna analysis. Samples were fixed with $4 \%$ saline formaldehyde. In the laboratory, meiofauna was elutriated (Boisseau, 1957 ) and sieved through a $0.067 \mathrm{~mm}$ mesh. The animals were identified to higher taxa and quantified under a stereoscopic microscope.

\section{Granulometry analysis}

Before sieving, samples were washed until the salt was completely removed and were left in a stove at a temperature of approximately $100^{\circ} \mathrm{C}$ until they were completely dry. Fifty-gram subsamples were sieved with electronic agitation $(15 \mathrm{~min})$ in a system of sieves with an eight-inch diameter. Sediments retained in each sieve were weighed, and sediment classification was carried out according to Wentworth (1922).

\section{Data analysis}

Data were analyzed statistically using both descriptive and multivariate statistics. A Spearman's rank correlation was applied to all data and will hereafter be referred to as Rs. As several parameters were determined, only significant correlations are discussed. A Principal Component Analysis were applied to log transformed data to ordinate water and sediment data and variables, with exception to meiofauna. Multidimensional scaling ordination (MDS), a multivariate analysis technique, was applied to the square root transformed abundance data of the meiofauna groups. An analysis of BIO-ENV was applied to evaluate which of the measured environmental parameters influences meiofauna community structure.

\section{RESULTS AND DISCUSSION}

\section{Organic and inorganic data}

DO, salinity, TPM, TOPM and SOM ranged, respectively, from 0.56 to $5.56 \mathrm{mg} / \mathrm{L}, 3.8$ to 32.9 , 15 to $40 \mathrm{mg} / \mathrm{L}, 13$ to $62 \%$ and 1 to $25 \%$ (Table 1 ). Orthophosphate, nitrite, nitrate, ammonia, chl a and FC ranged, respectively, from 0.2 to $3.2 \mu \mathrm{M}, 0.25$ to $1.14 \mu \mathrm{M}, 1.83$ to $20.19 \mu \mathrm{M}, 4.19$ to $49.23 \mu \mathrm{M}, 0.61$ to $6.72 \mu \mathrm{g} / \mathrm{L}$ and 14 to $5.0 \times 10^{4} \mathrm{MPN} / 100 \mathrm{~mL}$ of water (Tables 1 and 2). Sediments were mainly characterized by mud or sand. The gravel content was relatively low in all of the stations except for station 11, which presented higher percentages of gravel than mud (Fig. 2). Stations 2, 3, 4, 5, 8, 11, 12, 17 and 18 were classified as sandy, while stations $1,6,7,9,10,13,14,15$, and 16 were classified as muddy (Fig. 2).

According to Martin and collaborators (1976), DO concentrations for non-polluted estuaries range from 7 to $9 \mathrm{mg} / \mathrm{L}$. All concentrations found at GVES were below this range (Table 1), indicating that negative impacts on the system primarily occur on the Passagem Channel (stations 1-5), where values below $2 \mathrm{mg} / \mathrm{L}$ were observed at surface and indicated hypoxic conditions. These low concentrations can be attributed to sewage input (indicated by the negative correlation between dissolved oxygen and FC; Rs = $-0.59, P<0.05)$ because the availability of oxygen is lower when sewage input is higher. It is well known that in the presence of excessive OM, DO concentrations decrease considerably because it is used by bacterial reduction processes. Similar concentrations were observed at the effluent outfall of the Jardim Camburi Sewage Treatment Plant $(2.6 \pm 3.2 \mathrm{mg} / \mathrm{l}$; Barroso et al., 1997), a secondary treatment facility of a facul- 
Table 1 - Organic matter, fecal coliforms and physical-chemical parameters.

\begin{tabular}{|c|c|c|c|c|c|c|}
\hline Stations & $\begin{array}{l}\text { Dissolved } \\
\text { Oxygen } \\
\text { (mg/l) }\end{array}$ & Salinity & $\begin{array}{c}\text { Total } \\
\text { Particulate } \\
\text { Matter } \\
\text { (TPM) } \\
\text { (mg/l) }\end{array}$ & $\begin{array}{c}\text { Total } \\
\text { Organic } \\
\text { Particulate } \\
\text { Matter } \\
\text { (TOPM) } \\
(\%)^{\mathrm{a}}\end{array}$ & $\begin{array}{c}\text { Sediment } \\
\text { Organic } \\
\text { Matter (SOM) } \\
\% \mathrm{DW}^{\mathrm{b}}\end{array}$ & $\begin{array}{c}\begin{array}{c}\text { Fecal } \\
\text { coliforms }\end{array} \\
(\mathrm{MPN} / 100 \mathrm{ml})\end{array}$ \\
\hline 1 & 1.15 & 18.5 & 26.7 & 38 & 22 & $\geq 1600$ \\
\hline 2 & 1.96 & 17.9 & 32.0 & 62 & 3 & $\geq 1600$ \\
\hline 3 & 1.75 & 16.7 & 40.0 & 50 & 2 & 230 \\
\hline 4 & 1.95 & 16.5 & 28.0 & 43 & 3 & 130 \\
\hline 5 & 0.56 & 15.4 & 40.0 & 38 & 1 & 50000 \\
\hline 6 & 4.36 & 09.2 & 30.0 & 50 & 12 & 14 \\
\hline 7 & 4.72 & 03.8 & 23.3 & 43 & 17 & 50 \\
\hline 8 & 4.54 & 13.2 & 23.3 & 57 & 15 & 1400 \\
\hline 9 & 3.05 & 19.0 & 15.0 & 33 & 25 & 22 \\
\hline 10 & 3.39 & 19.9 & 30.0 & 17 & 23 & 600 \\
\hline 11 & 3.67 & 20.8 & 22.9 & 13 & 5 & 1100 \\
\hline 12 & 3.93 & 22.4 & 29.1 & 50 & 3 & 1300 \\
\hline 13 & 3.86 & 24.9 & 25.0 & 20 & 22 & 1100 \\
\hline 14 & 0.90 & 28.1 & 32.5 & 31 & 19 & 50000 \\
\hline 15 & 1.01 & 27.1 & 27.5 & 18 & 20 & 1300 \\
\hline 16 & 4.22 & 32.9 & 30.0 & 22 & 19 & 230 \\
\hline 17 & 4.52 & 32.6 & 32.5 & 23 & 4 & 130 \\
\hline 18 & 5.56 & 32.7 & 35.0 & 43 & 6 & 80 \\
\hline
\end{tabular}

tative pond system that drains into the Passagem Channel (at sampling station 3). Previous analyses at Passagem Channel station 3 showed concentrations

Table 2 - Nutrients and chlorophyll a data.

\begin{tabular}{|c|c|c|c|c|c|}
\hline Stations & $\begin{array}{c}\text { Orthophosphate } \\
\qquad(\mu \mathrm{M})\end{array}$ & $\begin{array}{l}\text { Nitrite } \\
(\mu \mathrm{M})\end{array}$ & $\begin{array}{l}\text { Nitrate } \\
(\mu \mathrm{M})\end{array}$ & $\begin{array}{c}\text { Ammonia } \\
(\mu \mathrm{M})\end{array}$ & $\begin{array}{c}\text { Chlorophyll a } \\
(\mu \mathrm{g} / \mathrm{L})\end{array}$ \\
\hline 1 & 2.86 & 1.14 & 5.20 & 42.8 & 5.98 \\
\hline 2 & 1.86 & 1.10 & 5.80 & 32.53 & 6.72 \\
\hline 3 & 1.86 & 0.92 & 7.95 & 17.75 & 5.02 \\
\hline 4 & 2.03 & 0.85 & 6.57 & 40.10 & 5.42 \\
\hline 5 & 3.20 & 0.69 & 4.31 & 49.23 & 4.54 \\
\hline 6 & 0.86 & 0.36 & 6.74 & 15.06 & 2.60 \\
\hline 7 & 0.70 & 0.28 & 12.31 & 4.19 & 1.98 \\
\hline 8 & 0.20 & 0.45 & 20.19 & 16.10 & 5.35 \\
\hline 9 & 0.70 & 0.91 & 11.37 & 18.19 & 2.80 \\
\hline 10 & 0.86 & 0.63 & 6.74 & 13.66 & 1.95 \\
\hline 11 & 0.86 & 0.59 & 9.61 & 12.97 & 1.58 \\
\hline 12 & 0.70 & 0.54 & 13.74 & 12.88 & 1.6 \\
\hline 13 & 0.70 & 0.52 & 9.16 & 14.8 & 1.38 \\
\hline 14 & 2.70 & 0.59 & 5.97 & 34.88 & 1.56 \\
\hline 15 & 1.36 & 0.62 & 6.85 & 16.97 & 1.57 \\
\hline 16 & 1.03 & 0.51 & 1.83 & 10.88 & 0.61 \\
\hline 17 & 0.86 & 0.46 & 2.72 & 9.66 & 0.85 \\
\hline 18 & 0.86 & 0.25 & 3.82 & 7.66 & 0.83 \\
\hline
\end{tabular}

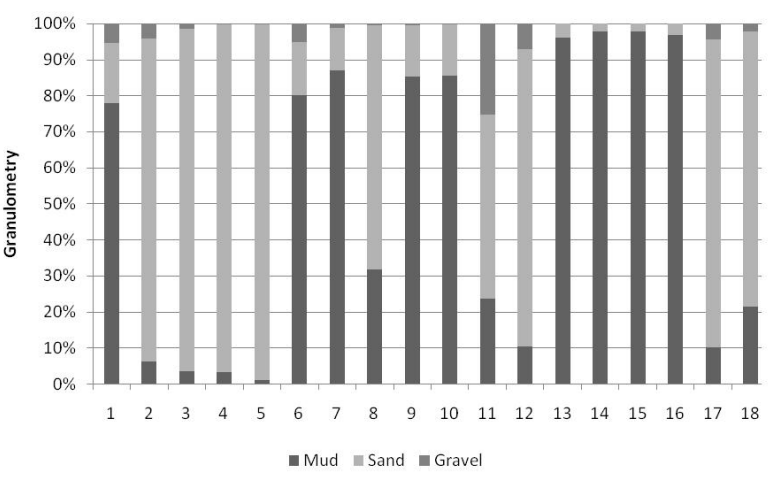

Figure 2: Values of the composition of sediment fractions (\%) in all sampling stations in The Great Vitoria Estuarine System (GVES).

between 19.4 and $42.4 \%$, indicating hypoxic conditions (Barroso, pers. comm.). Although this channel also receives non-treated sewage from local communities with low income and a lack of sewage treatment facilities, the continuing addition of treated wastewater rich in nutrients can cause algal blooms, leading to eutrophication (note the high values for nitrate, ammonia and chl $a$ at Passagem Channel, Stations 1-5, Table 2).

Both the lowest DO and the greatest TOPM values were observed at stations 1 to 5 (Table 1 ). Although stations 1 and 2 were located at estuarine and marine mixing waters, the convergence tide zone occurred from the Passagem Bridge to the north section of the Passagem Channel (stations 2 to 5 ; Fig. 1, Rigo, pers. comm.). In this section, water is partially trapped and moves to the north extremity of the channel during the ebb tide. Consequently, the residence time of the discharged solutes is increased, decreasing the self depuration capacity and increasing the load of nutrients, chl a, FC and OM (Tables 1 and 2). This suggests that this part of the GVES (Passagem Channel) was the most polluted and was eutrophic. The distinct hydrodynamics of the system, as discussed by Rigo \& Chacaltana (2006), seem to play a role in all of the biogeochemical characteristics of the GVES; aside from tidal influences, there are five tributaries (Fig. 1), which have distinct discharges distributed along the system.

Sampling stations 7 and 8 are located near the mouths of two Santa Maria river branches. The station 7 presented salinity values that were distinct from all the other area stations (Table 1), showing the influence of the river in the northern area of Vitoria Bay. On the other hand, station 8 presented salinity and FC levels that were similar to station 9. These similarities demonstrate the small fresh water influence at the GVES, which, according to Rigo \& Chacaltana (2006) caused the estuary to be classified as tide dominated.

Stations 10 and 11 are located at the São Pedro and Santo Antônio surroundings, respectively (Fig. 1). Due to the high population density and the low sewage 
treatment, this area is expected to have a high load of sewage discharge in natura, which was confirmed by the relatively high FC concentrations. The area between stations 13 and 17 , where the most urbanized region is located, showed high FC values, confirming a high sewage input. The sewage load enters into the system through the Aribiri River, the Leitão da Silva Avenue sewage channel and the pluvial drainage system (Fig. 1). Among these stations, station 14, which is located at the Aribiri River mouth, stands out due to its high FC, OM and orthophosphate concentrations (Table 1 and 2).

Similar to station 14 , stations $1,4,5$ and 8 presented the greatest dissolved orthophosphate concentrations, which were close to those observed in

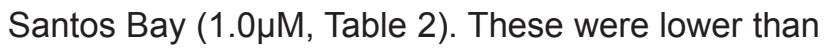
those expected for polluted estuaries (Braga et al., 2000) and could be explained by possible adsorption in particulate materials and by flocculation due to salinity changes (Braga et al., 2000). These processes were confirmed by the partial negative correlation found between salinity and TOPM (Rs $=-0.55, \mathrm{P}<0.05)$, although no direct correlation with orthophosphate was found. In addition, bioavailable orthophosphate for phytoplankton and macroalgae tends to be readily assimilated in tropical aquatic ecosystems so that its concentration tends to stay relatively low.

A similar situation was observed at station 12, where high concentrations of OM, FC, ammonia, nitrogen and phosphorus were found in both sediments and water. These high numbers were explained by the outflow from Rio Marinho, which currently functions as a sewage channel to Vitória Bay (Sá, 1995; Jesus et al., 2004).

High dissolved ammonia concentrations (26.65 $-60.50 \mu \mathrm{M}$ ) were found by Braga et al. (2000) at artificial drainage channels (in the region of Baixada Santista's). These concentrations were attributed to OM degradation and urea hydrolysis. In the current study, ammonia concentrations were similar (4.19 a $49.23 \mu \mathrm{M}$, Table 2) and can also be attributed to labile $\mathrm{OM}$ degradation due to the correlation with $\mathrm{FC}$ and to the strong negative correlation with $\mathrm{DO}(\mathrm{Rs}=0.52, \mathrm{P}$ $<0.05$ and $R s=-0.84, P<0.05$, respectively). These results indicate that the estuarine system had a high pollution level as the concentrations observed at all stations except for station 7 were considered to be above regular values observed in non-polluted estuaries (>5 MM, Day et al. 1987). In another study, Ma et al. (2005) found that high ammonia concentrations were attributed to denitrification and to dissimilatory nitrate reduction. The same process could be occurring in the present study system because the necessary conditions of low DO and high OM concentrations were observed (Libes, 1992).
The positive correlations between chl a, nitrite and ammonia dissolved nutrients (Rs $=0.62$; Rs = $0.66, P<0.05$, respectively) demonstrate that these nutrients are the main form of inorganic nitrogen absorbed by the autotrophic community at the GVES. The lack of correlation between nitrate and the other factors examined could be due to other processes such as the dissimilatory reduction mentioned earlier. The low nitrite concentration with respect to the total inorganic nitrogen could be due to either the low oxygen concentration or to rapid assimilation by phytoplankton. The presence of nitrite in the environment as a readily absorbed form supports the idea of an external source of nitrite (because nitrite is one of the limiting nutrients, it should occur at very low concentrations), probably from the sewage treatment station at sampling station 5 .

Although high values for sewage indicators are expected at station 18 because Praia da Costa City has a high population density and Praia da Costa Channel outflows on the station, aside from the OM and FS index, all measured variables were low. This is unexpected and could be explained by the high marine influence in the area, which could be trapping (upstream) or diluting this input or even masking the FC results, which are not resistant to high salinity. For a comparison, values of the FS index, which were analyzed in sediments, were high at this station.

\section{PCA analysis}

PCA was carried out on water and sediment data (Tables 1 and 2). PC1 and PC2 explained $51.2 \%$ of data variation. Temperature, DO, phosphate, nitrite, ammonia, mud and chl a presented the greatest loadings ( $>0.25$ or $<-0.25)$ for Axis 1 and nitrate, mud, sand, gravel, SOM, and FS Index showed the greatest loadings for Axis $2(>0.25$ or $<-0.25)$. Figure 3 shows the vectors of variables loadings. It seems that water parameters are responsible for axis 1 with a high loading for DO (31.6\%). The stations located at Passagem Channel (1-5) and station 14, which showed hypoxic

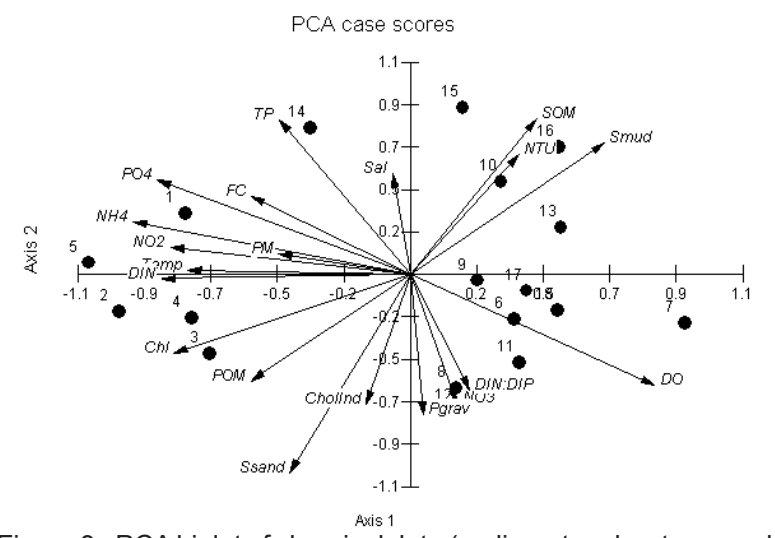

Figure 3 - PCA biplot of chemical data (sediment and water samples, stations 1-18). 
conditions, were grouped at left hand side of the Fig. 3. These stations also showed relatively high levels of nutrients, mainly ammonia, and FC. Chl a, TPOM, and TPM were distributed as a response to the high load of nutrients and low DO concentrations. Nitrogen speciation also showed to be related to DO. As expected, high nitrate concentrations were found where DO was relatively high. This shows how significant is the sewage impact on the physico-chemical parameters in this system.

On the other hand, it seems that the sediment parameters are responsible for axis 2 alterations. On opposite sides, there are SOM and mud with positive loadings and sand and gravel with negative scores. It is well known that mud has high content of OM because of its higher surficial area/volume and low oxygen penetration.

\section{Meiofauna data analysis}

The meiofauna was composed of 11 groups. Nematoda was the dominant group, with relative abundance values reaching $79 \%$, followed by Copepoda and Polychaeta, which represented $12 \%$ and $7 \%$ of the animals in the samples, respectively. The mean density of total meiofauna ranged from 5.2 to $459.1 \mathrm{ind} .10 \mathrm{~cm}^{-2}$ at stations 7 and 18, respectively. The highest values were observed at stations 2, 4, 12, 15, 16, 17 and 18 (Fig. 4). The Multidimensional Scaling analysis applied to the square root transformed total meiofauna density data showed a trend toward groups of samples (Fig. 5). One of these analyses aggregated samples from stations in which the highest values of both Nematoda density and salinity were registered.

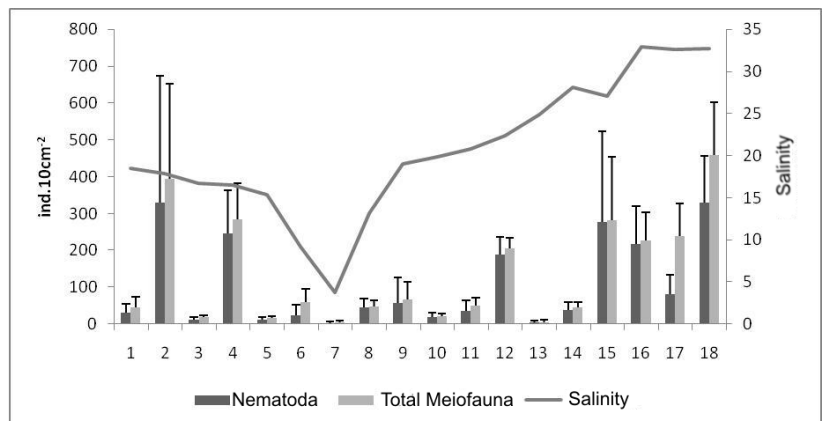

Figure 4 - Total meiofauna density, mean density of Nematoda (ind.10 $\mathrm{cm}^{-2}$ ) and salinity values observed in all sampling stations in the Great Vitoria Estuarine System (GVES).

The abundance of Nematoda in aquatic ecosystems is already well established (Coull, 1999), and hence, meiofauna community structure is mainly controlled by the trends of this group (Ozorio et al., 1999).

Mean densities of Meiofauna registered for the GVES were below the values found for several polluted estuarine environments (Jian et al., 1993; Ozorio et al., 1999; Somerfield et al., 2003) and were similar to

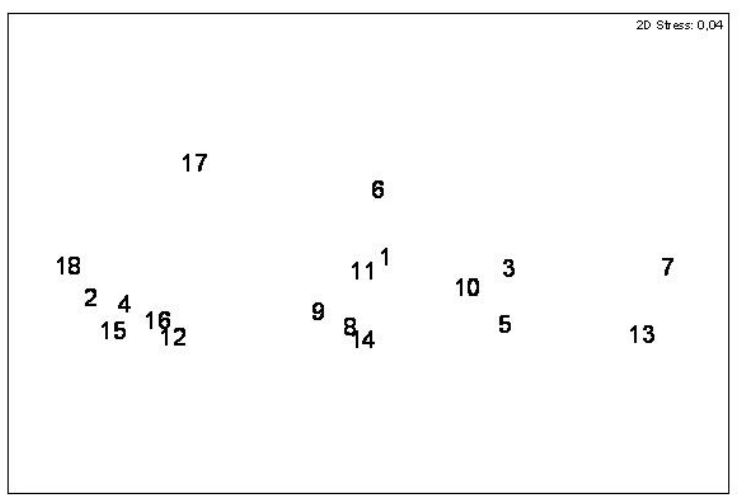

Figure 5 - Multidimensional Scaling (MDS) Analysis applied to meiofauna abundance data from all sampling stations in the Great Vitoria Estuarine System (GVES).

a polluted region in South Africa (Gyedu-Ababio et al., 1999). The meiofauna behavior of organic enrichment does not have a uniform response and sometimes increases in abundance when low to intermediate concentrations of organic matter are present. This increases food availability without depleting oxygen, and sometimes decreases abundances in regions of hypoxia/anoxia occur due to the high organic matter inputs of these regions (Sandulli \& Giudice, 1989; Sandulli \& De Nicola, 1991; Coull \& Chandler, 1993). Low meiofauna densities in organic polluted estuaries should be more closely related to toxic compounds present in sewage, such as metals, than to organic matter (Austen et al., 1994; Gyedu-Ababio et al., 1999).

In the present study, although the SOM values observed were considered to be high (1) and indicative of anthropogenic impacts, as mentioned earlier, there was no meaningful correlation between SOM and meiofauna density. It seems that meiofauna density tends to decrease when sediment $\mathrm{OM}$ values are above $10 \%$, except for at stations 15 and 16, which were not statistically meaningful. Gyedu-Ababio et al. (1999) also found that OM affects Nematoda communities in terms of density and diversity.

The correlation analysis highlights significant correlations between some grain size fractions and meiofauna groups. This correlation is well known (e.g., Gomes et al., 2002; Gyedu-Ababio et al., 1999) and will not be discussed further. Among all of the environmental parameters analyzed here, only salinity presented significant correlations with meiofauna community structure. Even those with low correlation values $(0.272)$ may be related to the large multiplicity of pollution sources at the GVES and the taxonomic resolution attained in the present work. Nematoda are highly diverse, and different genera and species are known to respond in different ways to different impacts. The low taxonomic resolution of the data, lead to the loss of a great deal of information (Hodda 
\& Nicholas, 1986). However, low meiofauna density values provided strong evidence that the GVES is polluted, although a large number of sources make it difficult to distinguish the main factors responsible. Within this generalized pollution situation, salinity is the most important factor influencing meiofauna spatial distribution patterns in the GVES as found in other studies (Soetaert et al.,1994; Coull, 1999; Gomes et al., 2002).

\section{CONCLUSIONS}

The results of this study showed that the tropical study system is currently undergoing an eutrophication process. Although stations 8 and 14 at Vitória Bay were highly impacted, Passagem Channel was the most contaminated area, while hypoxia mainly occurred at station 5. Sewage seems to be the main cause of hypoxia, as indicated by several parameters and by PCA and correlations tests.

The density of meiofauna had similar values to those observed at environments with similar levels of anthropogenic activity, but the meiofauna did not show any correlation with anthropogenic markers, possibly due to the multiple pollution sources and to the taxonomic resolution.

\section{ACKNOWLEDGEMENTS}

This study was funded by a grant from the Council for the Development of Science and Technology of Vitória City (FACITEC), for which the authors are thankful.

\section{REFERENCES}

APHA.; AWWA.; WEF.; 1999.Standard methods for the examination of water and wastewater. twenthy ed. American Public Health Association, Washington DC.

Austen, M.C.; McEvoy, A.J.; Warwick, R.M. 1994. The specificity of meiobenthic community responses to different pollutants: results from microcosm experiments. Mar. Pollut. Bull. 28(9):557-563.

Barroso, G.F.; Dias, C. Jr.; Güntzel, A. 1997. Preliminary assessment eutrophication potential of sewage effluents of four wastewater treatment plants in Espírito Santo State (Brazil). Verhand. Internat. Verein. Limnol. 26:666-670.

Bendschneider, K.; Robinson, R. J. 1952. A new spectrophotometric method for the determination of nitrite in sea water. J. Mar. Res., 11: 87-96.
Boisseau, J. P. (1957). Technique pour l'etude quantitative de la faune interstitielle des sables. C. r Congr Socs sav. Paris Sect. Sci. 1957: 117-119.

Braga, E.S.; Boneti, C.V.D.H.; Burone, L.; Bonetti Filho, J. 2000. Eutrophication and bacterial pollution caused by industrial and domestic wastes at the Baixada Santista estuarine system - Brazil. Mar. Pollut. Bull. 40 (2):165-173.

Coull B.C. 1999. Role of meiofana in estuarine softbottom habitats. Aust. J. Ecol. 24:327-343.

Coull, B.C.; Chandler, G.T.1992. Pollution and meiofauna - field, laboratory and mesocosm studies. Oceanogr. Mar. Biol. 30:191-271.

Day, J.W.; Hall, C.A.S.; Kemp, W.M.; Yánez-Arancibia, A. 1987. Estuarine ecology. John Wiley and Sons, New York, 558p.

Gomes, C.A.A.; Santos, P.J.P.; Alves, T.N.C.; Rosa Filho, J.S.; Santos, L.P.S. 2002. Variação temporal da meiofauna em área de manguezal em Itamaracá - Pernambuco. Atlântica. 24(2):89-96.

Gyedu-Ababio, T.K.; Furstenberg, J.P.; Baird, D.; Vanreusel, A. 1999. Nematodes as indicators of pollution: a case study from the Swartkops River system, South Africa. Hydrobiologia. 397:155-169.

Hodda, M., Nicholas,W.L., 1986.Nematode diversity and industrial pollution in the Hunter River Estuary, NSW, Australia. Mar. Pollut. Bull.17(6):251-255.

Jesus, H.C.; Costa, E.A.; Mendonça, A.S.F.; Zandonade, E. 2004. Distribuição de metais pesados em sedimentos do sistema estuarino da Ilha de Vitória-ES. Quim. Nova 27(3):378-386.

Jian, L.; Vincx, M. 1993. The temporal variation of intertidal nematodes in Westerschelde. I. The importance of an estuarine gradient. Neth. J. Aquat. Ecol. 27:319-326.

Johannessen, T.; Dahl, E. 1996. Declines in oxygen concentrations along the Norwegian Skagerrak coast, 1927-1993: A signal of ecosystem changes due to eutrophication? Limnol. Oceanogr. 41(4):766-778.

Libes, S. 1992. An Introduction to Marine Biogeochemistry. John Wiley and Sons (WIE), New York, 734p.

Martin, J. M.; Meybeck, M.; Salvadori, F.; Thomas, A. J.1976. Polution chimique des estuaries: etatactual des Connaissances. Rapports Scientifiques et Techniques. 22 (5):184-224

Murphy, J.; Riley, J.P. 1962. A modified single solution method for the determination of phosphate in natural waters. Anal. Chim. Acta, 27: 31-36.

Ozorio, C.P.; Bemvenuti, C.E.; Rosa, L.C. 1999. Comparação da meiofauna em dois ambientes estuarinos da Lagoa dos Patos, RS. Acta Limnol. Bras. 11(2):29-39.

Paerl, H.W. 2009. Controlling eutrophication along 
the freshwater-marine continuum: dual nutrient $(\mathrm{N}$ and $\mathrm{P}$ ) reductions are essential. Estuar. Coast. 32(4):593-601.

Rigo, D.; Chacaltana, J.T.A. 2006. Computational modelling of mangrove effects on the hydrodynamics of Vitoria Bay, Espirito Santo - Brazil. J. Coastal. Res. 3:1543-1545.

Sá, H.S. 1995. Caracterização da fauna de crustáceos (Crustacea) do manguezal de Cariacica, Espírito Santo, Brasil. Caderno de Pesquisada UFES 4:15-26.

Sandulli, R.; Giudici, M.N. 1989. Effects of organic enrichment on meiofauna: a laboratory study. Mar. Pollut. Bull. 20(5):223-227.

Sandulli, R.; Nicola, M. 1991. Responses of meiobenthic communities along a gradient of sewage pollution. Mar. Pollut. Bull. 22(9):463-467.

Simpson, S. 2001. Shrinking the dead zone: political uncertainty could stall a plan to rein the deadly waters in the Gulf of Mexico. Sci. Am. 285(1):10-11.

Soetaert, K.; Vincx, M.; Wittoeck, J.; Tulkens, M.; Gansbeke, V.D. 1994. Spatial patterns of Westerschelde meiobenthos. Estuar. Coast. Shelf S. 39:367-388.
Somerfield, P.J.; Vonseca-Genevois, V.G.; Rodrigues, A.C.L.; Castro, F.J.V.; Santos, G.A.P. 2003. Factors affecting meiofaunal community structure in the Pina Basin, an urbanized embayment on the coast of Pernambuco, Brazil. J. Mar. Biol. 83:1209-1213.Sterza, J.M.; Ovalle, A.R.C.; Fernandes, L.F.L. 2008. Zooplankton distribution and abundance related to the hydrochemistry in a tropical bay (south-east Brazil). Cah. Biol. Mar. 49:229-245.Strickland, J.D.H.; Parsons, T.R. 1972. A pratical handbook of seawater analysis. 2ed. Fish. Res. Bd. Can. Bull., Ottawa, 311p.

Wentworth, C.K. 1922. A scale of grade and class terms for clastic sediments. JSTOR. 30:377-392.

Wood, E. D. F.; Armstrosg, F. A. Richards, E. A. 1967. Determination of nitrate in sea water by cadmiumcopper reduction to nitrite. J. hlar. Biol. Ass. U.K. 47: 23-31.

Submetido: Fevereiro/2014 Revisado: Novembro/2015 Aceito: Março/2016 